\begin{tabular}{llllllll}
$\mathbf{R}$ & $\mathbf{O}$ & $\mathbf{Z}$ & $\mathbf{P}$ & $\mathbf{R}$ & $\mathbf{A}$ & $\mathbf{W}$ & $\mathbf{Y}$ \\
\hline
\end{tabular}

ROCZNIKI HUMANISTYCZNE

Tom LXIX, zeszyt 4 - 2021

DOI: http://doi.org/10.18290/rh21694spec-1

TOMASZ ROKOSZ

RADOSŁAW WILEŃSKI SAC

\title{
KUŹNIA CHARAKTERU, KORZENIE ŚWIĘTOŚCI \\ - WIEŚ ZUZELA, MIEJSCE URODZENIA \\ I PIERWSZYCH LAT ŻYCIA \\ KARDYNAŁA STEFANA WYSZYŃSKIEGO
}

Temat, który podejmujemy, wydaje się istotny przede wszystkim w dwóch aspektach. Po pierwsze, oczywistą kwestią jest szczególny czas beatyfikacji kardynała Stefana Wyszyńskiego (z powodu pandemii koronawirusa została ona przesunięta z 7 czerwca 2020 r. na 12 września 2021 r.). Uchwałą Sejmu i Senatu RP prymas Stefan kardynał Wyszyński został także patronem roku 2021, na który przypada okrągła, 120. rocznica urodzin i 40. rocznica śmierci Prymasa Tysiąclecia, a także 75 . rocznica przyjęcia święceń biskupich. W konsekwencji w ostatnim czasie można zauważyć wiele cennych inicjatyw dotyczących jego osoby. W tym kontekście sięgnięcie do okresu dzieciństwa Prymasa Tysiąclecia wydaje się naturalne i zarazem znamienne, powszechnie bowiem uważa się, że to właśnie wczesny okres życia człowieka kształtuje go najsilniej - jest decydujący dla całej jego późniejszej drogi życiowej.

Lata spędzone w Zuzeli nie były zapewne dla Stefana Wyszyńskiego tak beztroskie, jak można mniemać, ale z pewnością zaważyły na jego dalszych wyborach życiowych i wielkich dokonaniach. Z perspektywy czasu Zuzela

Dr hab. ToMAsz Rokosz - Katolicki Uniwersytet Lubelski Jana Pawła II, Wydział Nauk Humanistycznych, Instytut Nauk o Sztuce, Katedra Etnomuzykologii i Hymnologii; e-mail: tomasz.rokosz@kul.pl; ORCID: https://orcid.org/0000-0001-6666-6196.

Mgr RADOSŁAW WILEŃSKI SAC - pochodzący z parafii Zuzela, wykładowca muzyki w Wyższym Seminarium Duchownym Księży Pallotynów w Ołtarzewie, duszpasterz i katecheta w Sanktuarium Miłosierdzia Bożego w Ożarowie Mazowieckim; e-mail: wilkedar@poczta.fm; ORCID: https://orcid.org/0000-0002-1700-7765. 
jawi się jako swoisty raj utracony, zwłaszcza w kontekście późniejszej przeprowadzki do Andrzejewa, gdzie wkrótce zmarła matka Stefana Wyszyńskiego, a miał on wówczas zaledwie 9 lat. Możemy więc rekonstruować ówczesną Zuzelę $\mathrm{z}$ początku XX wieku jako wyjątkowe miejsce w życiu późniejszego Prymasa Polski, w którym zaznał dobrodziejstwa pełnej rodziny - matczynej i ojcowskiej miłości. Bez wątpienia na jego późniejsze życie wpłynęły też relacje rodziców, które obserwował w Zuzeli, także ich stosunek do wiary chrześcijańskiej. Wspominał o tym po latach w istotnym kontekście - pamięć prostej wiary rodziców, bezgranicznego zaufania i zawierzenia Bogu i Jego Matce stały się dla Stefana Wyszyńskiego wzorem i główną motywacją przyjęcia biskupstwa w Lublinie, które wahał się przyjąć:

Podobało się Bogu, aby mnie doprowadzić po wielu latach służby kapłańskiej do pełni kapłaństwa. W roku 1946 otrzymałem powołanie na biskupa lubelskiego. Byłem tym mocno przestraszony, ponieważ czułem, że przerasta to moje siły, zwłaszcza $\mathrm{w}$ tak trudnych czasach, jakie przed Kościołem Bożym stanęły w okresie powojennym, opierałem się woli Stolicy Świętej. (...) Szukałem więc pomocy. Przypomniałem sobie modlitwę mojej matki i mojego ojca przed obrazem Matki Boskiej Częstochowskiej tutaj, w kościele parafialnym w Zuzeli. Postanowiłem wejść w ich ślady. Dlatego po konsekrację biskupią pojechałem na Jasną Górę. Odtąd życie moje związało się już z Jasną Górą. (...) Dlaczego wam to mówię, dzieci Boże? Dlatego, że są to owoce żywej pobożności, religijności, którą otrzymałem od moich rodziców, modlących się właśnie tutaj w kościele zuzelskim, przy czczonym przez was obrazem Matki Bożej Częstochowskiej. (Wyszyński, Kazanie 12-13)

Zuzelę można lokalizować w perspektywie symbolicznej między wschodem a zachodem - między Jasną Górą a Ostrą Bramą. W rodzinie Wyszyńskich splatają się jakby dwie formacje, dwie formy pobożności maryjnej:

Mój ojciec z upodobaniem jeździł na Jasną Górę, a moja matka do Ostrej Bramy. Razem się potem schodzili w nadbużańskiej wiosce, gdzie się urodziłem, i opowiadali wrażenia ze swoich pielgrzymek. Jako mały brzdąc podsłuchowałem to, co stamtąd przywozili. (Raina 14)

Ksiądz Prymas, wspominając kościół swojego chrztu i dzieciństwa, a przede wszystkim swojego ojca, opowiadał, że z tego okresu pozostały mu w pamięci dwa obrazy: Matki Bożej Częstochowskiej i Matki Bożej Ostrobramskiej, przed którymi modlili się jego rodzice. (Ryszka 14)

W wywiadzie przeprowadzonym na potrzeby niniejszego artykułu z Andrzejem Karpiem, bliskim krewnym matki Stefana Wyszyńskiego, tak opowiadał on o potrzebie głębszego opisania Zuzeli, jako miejsca urodzenia i pierwszych lat życia Stefana Wyszyńskiego: 
Moim marzeniem jest to [...], że tutaj są korzenie Kardynała, tutaj się wychował, tu kształtował się jego charakter i miłość do ojczyzny, a nie w Andrzejewie, czy Wrociszewie. Po latach, w 1953 roku, powiedział: „Kocham Ojczyznę więcej niż własne serce i wszystko, co czynię dla Kościoła, czynię dla niej”. (Karp, wywiad 2021).

Warto posłuchać głosu rodziny Prymasa. Przyjrzyjmy się więc na początku genius loci tego znaczącego dla historii Polski i polskiego Kościoła miejsca, aby później skierować wzrok na główne postaci naszej opowieści - Stefana Wyszyńskiego i jego Rodziców ${ }^{1}$.

Od XV wieku dokumenty wzmiankują, że parafia Zuzela była prowadzona przez Kanoników Regularnych Laterańskich z Czerwińska². Następnie funkcjonowała pod zwierzchnictwem biskupa płockiego, a od 1925 r. łomżyńskiego (Czarnowski 7-9).

Miejscowość Zuzela znajduje się na pograniczu Mazowsza i Podlasia (formalnie na Mazowszu), w diecezji łomżyńskiej. Jest położona na prawym brzegu rzeki Bug, pośród łąk, lasów i pól. Głównym zajęciem rdzennych mieszkańców tych ziem było rolnictwo. Badania archeologiczne wykazały, że wieś, której nazwa prawdopodobnie pochodzi od rzeczownika żużel, oznaczającego produkt odpadowy procesów hutniczych metali (Czarnowski 12), posiada ślady osadnictwa sięgające epoki kamiennej. Odnaleziono także ślady wskazujące na istnienie osadnictwa wczesnośredniowiecznego. Ważnym znaleziskiem okazał się fragment żużla z XIII wieku, co byłoby spójne z wyrażonym przypuszczeniem dotyczącym etymologii nazwy miejscowości. Nazwę tę odnajdujemy już w dokumentach z XII wieku. Położenie na prawym brzegu Bugu sprzyjało rozwojowi wsi, łączącej szlak handlowy lądowy oraz wodny. Położenie wioski było na tyle ważne, że wpłynęło na nadanie jej praw miejskich, funkcjonujących od XII do XV wieku (w późniejszych wiekach zostały one utracone) (por. Bystroń, Kultura ludowa 101-125).

10 lipca 1448 r. w Zuzeli powstała parafia erygowana przez biskupa płockiego Pawła Giżyckiego, obejmująca tereny po obu stronach Bugu, a jej centrum stał się drewniany kościół. Uposażył ją natomiast o. Rafał, ówczesny opat klasztoru Kanoników Laterańskich z Czerwińska. Liczba ludności parafii (Czarnowski 37) nieznacznie się zmieniała, a spowodowane było to między

\footnotetext{
${ }^{1} \mathrm{~W}$ artykule wykorzystano fragment pracy magisterskiej Radosława Wileńskiego SAC Ludowe śpiewy religijne w obrzędzie pogrzebowym ze wsi Gąiorowo (parafia Zuzela $w$ diecezji tomżyńskiej). Analiza materiałów terenowych z lat 2019-2020. Promotor: dr hab. Tomasz Rokosz.

${ }^{2}$ W 1796 r. nastąpiła kasata Zakonu Kanoników Regularnych Laterańskich z Czerwińska (Krysztopa, wywiad 2021).
} 
innymi walkami toczonymi na jej terenie oraz chorobami zakaźnymi (cholera w latach 1831 i 1905 r.). Na początku XIX wieku we wsi i okolicach oprócz katolików mieszkało około 200 Żydów oraz nieliczni prawosławni i ewangelicy (Czarnowski 37). Tereny parafii stanowiły głównie wioski szlacheckie posiadaczy ziemskich. Rolnictwo do połowy XIX wieku stanowiło jedyny środek utrzymania mieszkańców całej parafii. U początku XIX wieku do parafii należało 36 wiosek.

Od przynajmniej sześciu wieków społeczność parafialna posiadała w $\mathrm{Zu}$ zeli świątynię - dziś jest to neogotycki kościół z czerwonej cegły, zbudowany w latach 1908-1913 (fot. 1). Warto jednak przypomnieć, że już w dokumentach posiadłości biskupów płockich (z 1239 r.) widnieje informacja o Zuzeli jako „wiosce z kościołem” (Czarnowski 14). Na początku XV wieku inny dokument informuje o kościele św. Mikołaja, a dokument uposażenia parafii określa wezwanie kościoła jako Trójcy Świętej i św. Leonarda (Czarnowski 21). W 1726 r. powstał nowy kościół pw. Przemienienia Pańskiego, który został konsekrowany w 1792 r. W 1905 r. proboszcz Antoni Lipowski otrzymał zgodę na budowę kościoła murowanego, którego projektantem był warszawski inżynier Ludwig Dziekoński. Budowę tego właśnie kościoła wspierała rodzina Wyszyńskich, a zwłaszcza Stanisław Wyszyński, pracujący wówczas w parafii Zuzela jako organista. W 1913 r. za nowego już proboszcza, ks. Antoniego Pomirskiego, kościół został konsekrowany przez bpa Juliana Nowowiejskiego i otrzymał wezwanie Przemienienia Pańskiego. Drewniany kościół rozebrano. Na chórze nowego kościoła zamontowano dwunastogłosowe organy. W 1944 r. kościół został częściowo zniszczony, a całkowitemu zniszczeniu uległy organy. Odbudowa kościoła trwała od 1957 r. przez 10 lat (Czarnowski 21-27).

Parafia od początku swego istnienia posiadała przykościelny cmentarz grzebalny. Przeznaczono również teren pod grzebanie samobójców oraz oddzielny dla zmarłych na zakaźne choroby. Po zniszczeniu cmentarza podczas powstawania listopadowego w 1830 r. nowy cmentarz został erygowany w innym miejscu w 1840 r., a jego granice zabezpieczono w latach 18721891 kamiennym murem (fot. 2). Dokumenty wizytacji dziekańskich wskazują, że zostało na nim wydzielone miejsce dla nieochrzczonych dzieci. Stary cmentarz przy drewnianym kościele pozostał aż do jego likwidacji w 1921 r. Na cmentarzu znajdowało się pomieszczenie, gdzie do 1865 r. składano kości zmarłych, które odkopywano na cmentarzu, szykując nowy grób. Chowano je później we wspólnym grobie. W 1913 r. na cmentarzu powstała murowana kaplica, odrestaurowana w 1927 r. (Czarnowski 31-35). 
Aktualnie Zuzela jest wsią liczącą 174 mieszkańców. Tutejsza zaś parafia rozciąga się na 17 okolicznych wiosek ${ }^{3}$ i liczy w sumie 1038 wiernych. Obecnie zwierzchnikiem jest biskup diecezjalny łomżyński Janusz Stepnowski, a posługę duszpasterską pełni proboszcz ks. Jerzy Krysztopa.

Jednoczącymi całą parafię Zuzela świętami były odpusty: Przemienienia Pańskiego, Najświętszej Maryi Panny Różańcowej, św. Mikołaja i ostatni odpust, będący pamiątką poświęcenia kościoła. Od początku XX wieku do dziś obchodzi się dwa z nich Przemienienia Pańskiego oraz św. Mikołaja Biskupa. W parafii zawsze prężny był kult maryjny. Rozwinął się on najmocniej w początku XX wieku z racji możliwości pielgrzymowania do sanktuariów maryjnych takich jak Częstochowa czy Ostra Brama w Wilnie (Molka 8-13).

Opisywana przez ks. Roberta Czarnowskiego w książce Parafia Zuzela. Dzieje $i$ duszpasterstwo $w$ latach 1796-1925 historia parafii Zuzela potwierdza zaangażowanie proboszczów w rozwój parafii, na co może wskazywać nieustanne dążenie do posiadania własnego kościoła, a także parafialne księgi metrykalne, ukazujące liczne uczestnictwo wiernych w życiu sakramentalnym (Czarnowski 87-118).

Dla ludzi, którzy w większości przez całe życie nie opuszczali terenu swojej parafii, proboszcz pełnił funkcję nauczyciela i duchowego przewodnika. Na wiernych oddziaływał głównie przez posługę kaznodziejską. Wygłaszał nauki o sprawach wiary, ale też poruszał zagadnienia etyczne. Jak pisze Jan Bystroń „(...) dla ogromnej większości włościan kazania były jedynym źródłem wiadomości o szerokim świecie, a świat ten zaczynał się już poza granicami parafii, poza które najczęściej nie wychodzono" (Bystroń, Etnografia 10). Oddziaływanie proboszcza na lokalną społeczność było związane także z bezpośrednim kontaktem z parafianami poprzez prowadzoną katechizację, spowiedź czy szeroko rozumiane doradztwo ${ }^{4}$.

Przedstawiony opis parafii Zuzela pozwala nam zrekonstruować warunki zewnętrzne, w których wychowywał się i dorastał Stefan Wyszyński. Jego ojciec, Stanisław Wyszyński, „uczył się zawodu organisty u Alojzego Serwatki, organisty w parafii w Kamieńczyku. Stanisław pochodził z miejsco-

\footnotetext{
${ }^{3}$ Są to wsie: Gąsiorowo, Godlewo Mierniki, Godlewo Milewek, Godlewo Warsze, Godlewo Wielkie, Kałęczyn, Opatowina, Podgórze Gazdy, Pętkowo Wielkie, Pułazie, Smolewo Parcele, Smolewo Wieś, Zakrzewo Kopijki, Zakrzewo Słomy, Zakrzewo Wielkie, Zgleczewo Panieńskie, Zgleczewo Szlacheckie.

${ }^{4}$ Należy tu wspomnieć postać szczególną, gdy chodzi o zasługach dla formacji religijnej wiernych - ks. Walentego Załuskę, wybitnego polskiego teologa, autora licznych prac z zakresu teologii i historii, proboszcza w Zuzeli w latach 1919-1927 (por. Czarnowski 60-62).
} 
wości Gać. Z Gaci do Kamieńczyka było kilka kilometrów" (Karp, wywiad $2021)^{5}$. Pracę organisty rozpoczął najpierw w Gałkówku (por. Karp, „W przeddzień beatyfikacji” 75) nieopodal Łodzi:

W Gałkowie długo nie pracował. Miejscowość ta w owym czasie należała do zaboru rosyjskiego. Stanisław Wyszyński nie ukrywał swojego patriotyzmu, co się władzom carskim nie podobało. (...) Groziło mu aresztowanie. Wyjechał więc do Prostyni, gdzie pracował jako organista. Przyszła Jego żona i jej rodzina, jak i on $\mathrm{z}$ rodziną chodzili przed laty do kościoła parafialnego w Kamieńczyku. Rodziny Wyszyńskich i Karpiów znały się od dawna, a Stanisław i Julianna przyjaźnili się. Z czasem przyjaźń przerodziła się w miłość i 4 maja 1899 roku Stanisław i Julianna rozpoczęli tu wspólną sakramentalną drogę małżeńską. (Karp, wywiad 2021)

W parafii w Prostyni (obecnie Gmina Małkinia Górna) ojciec Prymasa Tysiąclecia pracował nie tylko jako organista, ale także działacz społeczny i kulturalny (Śliwowa 7). Stefan Wyszyński urodził się już w Zuzeli, gdzie przez kolejne dziewięć lat zamieszkiwała rodzina Wyszyńskich, jako ich drugie dziecko 3 sierpnia $1901 \mathrm{r}$. Narodziny zostały odnotowane w akcie chrztu nr 148 z 1901 r. Dokument sporządzony jest w języku rosyjskim według nakazu, który wydano w Królestwie Polskim ${ }^{6}$. Stefan został ochrzczony w drewnianym kościele w dniu narodzin. Kościół ten został rozebrany z chwilą powstania kościoła murowanego w 1913 r., zachowana jednak została chrzcielnica (fot. 3), którą umieszczono w centralnym miejscu $\mathrm{w}$ nawie głównej nowego kościoła, oraz obraz Matki Bożej Częstochowskiej, przed którym modlił się mały Stefan i jego ojciec Stanisław. Obraz pochodzi z 2. połowy XIX wieku. Proboszcz Krysztopa wskazuje, że tu zapewne rodziły się pierwsze myśli Stefana Wyszyńskiego o kapłaństwie (Krysztopa, wywiad 2021).

Stanisław Wyszyński pełnił w kościele funkcję organisty, ale także prowadził księgi parafialne. Choć zabór rosyjski karał postawy patriotyczne, ojciec próbował swoim dzieciom zaszczepić ducha polskości. Uczył je potajemnie historii, co stało się fundamentem dla przyszłej postawy patriotycznej wielkiego Polaka - Stefana kardynała Wyszyńskiego. Na kartach jego biografii spisanej przez Ewę Czaczkowską można znaleźć informację, że dom Wyszyńskich, co było w tych czasach rzadkością, był zaopatrzony w książki: religijne - Biblię, żywoty świętych, przyrodnicze, historyczne i literaturę

\footnotetext{
${ }^{5}$ Wsie Gać i Kamieńczyk należą obecnie do powiatu wyszkowskiego.

${ }^{6}$ Od 1 stycznia 1868 r. wpisy do ksiąg metrykalnych sporządzano tylko w języku rosyjskim (por. Czarnowski 93).
} 
piękną - Mickiewicz, Kraszewski i inni. Stanisław podjął także prenumeratę pisma katolickiego Ziarno (Czaczkowska 31). Bliska współpraca Stanisława z Kościołem wpłynęła w naturalny sposób także na religijne wychowanie jego dzieci. Pewien obraz, który towarzyszył mu przez całe życie, tak zapisał się w małym Stefanie:

Nie rozumiałem wtedy, dlaczego ojciec tyle czasu klęczy przed tym obrazem. Dziś to rozumiem. Był wierny darowi modlitwy do ostatnich swoich dni. Dziś rozumiem jego modlitwy i służbę, którą traktował nie jako zawód, ale jako powołanie sługi ku chwale Bożej, grając i śpiewając w dawnej, zabytkowej drewnianej świątyni. (Śliwowa 9)

Nad łóżkiem małego Stefana wisiały dwa obrazy: Matki Bożej z Częstochowy i Matki Boskiej Ostrobramskiej z Wilna. Były to dwa obrazy, którym rodzice oddawali szczególną cześć, a które zaraz po przebudzeniu każdego dnia oglądał syn. Codziennie w domu Wyszyńskich odmawiany był wspólny wieczorny różaniec. Można już w tym momencie odnajdywać źródła wielkiego zawierzenia kardynała Wyszyńskiego Maryi, czego punktem kulminacyjnym był Akt oddania Polski 3 maja 1966 r. na Jasnej Górze w macierzyńską niewolę Maryi, Matki Kościoła, w wielki Jubileusz 1000-lecia Chrztu Polski (por. Wyszyński, Wypetniamy Jasnogórskie Śluby Narodu 7).

W tym właśnie kontekście należy postrzegać dzieciństwo Stefana Wyszyńskiego, choć warto pamiętać, że status organisty i jego rodziny był wyższy niż status zwykłych parafian. W związku z powinnościami ojca przyszły Prymas Tysiąclecia był też od dziecka bliżej liturgii (od piątego roku życia był ministrantem) i wszelkich spraw Kościoła. Dom państwa Wyszyńskich uformował osobowość kardynała. Rodzice wpajali mu szacunek do drugiego człowieka, ale i do pracy ludzkiej oraz jej symbolu - chleba. Szacunek ten wpajany był poprzez ucałowanie chleba, który znalazł się na podłodze, pocałowaniem ręki pomagającej sąsiadki lub poprzez odwiedziny ciężko chorego sąsiada (Micewski 19).

Wielkim autorytetem dla przyszłego Prymasa Tysiąclecia był jego ojciec. Znamienne jest następujące zdarzenie $\mathrm{z}$ dzieciństwa, które tak wspomina po latach:

Kiedyś jako mały chłopiec wędrowałem ciemną nocą ze swoim ojcem od stacji kolejowej do wioski rodzinnej mojego dziada. Lękałem się bardzo, a ojciec pytał: czegóż ty się boisz? Bałem się, że ojciec w lesie zagubi drogę, ale on ją dobrze znał. Zatrzymaliśmy się przy krzyżu, który stał przy drodze, i odpoczywaliśmy. Czułem się bezpieczny. (Raina 14) 
Ojciec rodziny podjął się nie tylko funkcji organisty i pracownika parafialnej kancelarii, ale także był „wiejskim społecznikiem” (Czaczkowska 30). Współorganizował straż ogniową, teatr ludowy i pomagał chłopom w kontaktach z urzędami. Wnioskować przez to można, że dom Wyszyńskich w Zuzeli był często odwiedzany przez mieszkańców wioski, a nawet całej parafii. Jak wspominają mieszkańcy Zuzeli: „Organista to był ktoś, nie było tam w domu wielkiego bogactwa, ale biedy też nie było" (Czaczkowska 30). Wspominają też, że dom Wyszyńskich był zawsze zadbany. Oryginalny budynek, w którym mieszkali Wyszyńscy, został zniszczony podczas wojny. Odtworzono go w 1990 r., obecnie jest wpisany do rejestru zabytków. Stanisław Wyszyński cieszył wielkim zaufaniem księdza proboszcza Lipowskiego oraz parafian. Poza sprawami kancelaryjnymi powierzone mu zostały także sprawy gospodarcze i finansowe budowy nowej świątyni (por. Kindziuk 15):

Ale co najbardziej zapadło mi w pamięć, to rozpoczęcie budowy tego kościoła. Wtedy budowano inaczej, z wielkim trudem. Stroną gospodarczą i rachunkową budowy zajmował się mój Ojciec. Do niego należało załatwianie wielu spraw z murarzami i majstrami. Pamiętam pierwsze wykopy pod fundamenty tej świątyni. Widziałem olbrzymie sterty wydobytych przy kopaniu fundamentów kości waszych pradziadów, dziadów i ojców, które później uroczystym pogrzebem pochowano pod tą świątynią. - Pamiętam, że niekiedy byliśmy wzywani na pomoc, gdy zabrakło cegły na rusztowaniach. (Wyszyński, Kazanie 10-11)

W kwestiach związanych z budową murowanego kościoła w Zuzeli, w które angażowała się bezpośrednio rodzina Wyszyńskich, można upatrywać symboliczną presupozycję odbudowy wspólnoty Kościoła polskiego po pożodze II wojny światowej oraz w trakcie oddziaływania ideologii komunizmu (por. Orszulik 46-50), realizowanej pod przewodnictwem Prymasa Tysiąclecia. Uprawniona wydaje się teza, że jego dzieciństwo, ze wszystkimi trudnościami, stało się zalążkiem późniejszej walki o wartości duchowe i poszanowanie godności człowieka (por. Stefaniak 3). Nawet w obliczu niebezpieczeństwa śmierci i więzienia zachował niezłomną postawę, którą motywował Polaków do walki o wolność 7 .

Rodzina Wyszyńskich przeprowadziła się w 1910 r. (Stefan Wyszyński miał wówczas niecałe 9 lat) do Andrzejewa (około $15 \mathrm{~km}$ od Zuzeli). Tam znaleźli większe mieszkanie, gdzie mogła pomieścić się rodzina z pięciorgiem dzieci. Ojciec również tam był organistą. Przenosiny te nie były chyba jednak postrzegane pozytywnie przez Wyszyńskich, skoro ks. Krysztopa tak o nich wspomina:

\footnotetext{
${ }^{7}$ Więcej na temat zob. Wyszyński, Zapiski więzienne.
} 
Ojciec, Stanisław, gdy wiózł swoją żonę do Andrzejewa, matka powiedziała: „Stasiu wieziesz mnie na pewną śmierć”. Mówiła to w kwietniu 1910 roku, na kilka miesięcy przed swoją śmiercią. W duchu macierzyńskim. Nie chciała opuszczać Zuzeli, ponieważ była bardzo zżyta z parafią, pomimo tego, że nie była naszą parafianką. Pochodziła przecież z parafii Kamieńczyk nad Bugiem, z miejscowości Fidest. (Krysztopa, wywiad 2021)

Tu po niedługim czasie, 31.10.1910 r,. w wieku zaledwie 33 lat Julianna Wyszyńska zmarła, a 5 dni później zmarła także jej najmłodsza córka Zosia. Tragedia ta odcisnęła trwałe piętno na dalszym życiu Stefana Wyszyńskiego. Fakty te zapewne wzmacniały także w pamięci rodziny przyszłego Prymasa pozytywny status Zuzeli - kraju szczęśliwego dzieciństwa.

W dalszym wychowaniu osieroconych dzieci pomagała ojcu Stefana Wyszyńskiego przyjaciółka Julianny - Eugenia Godlewska, która wkrótce została drugą żoną Stanisława i kochającą matką dla pasierbów. Stefanowi przybyło też przyrodnie rodzeństwo, zrodzone z małżeństwa Stanisława i Eugenii. Zuzela kojarzyła się jednak późniejszemu kardynałowi przez całe życie z obecnością swojej rodzonej matki. Zawsze miał przy sobie jej zdjęcie i wierzył, że jest jego orędowniczką w niebie: „Nieraz, kiedy stoję na ambonie albo jest przede mną wyjątkowo trudne i ważne zadanie, mam wrażenie, że stoi za mną moja przedwcześnie zmarła Matka, że ona mi doradza i podpowiada” („Radujcie się, Pan jest blisko” 18). Śmierć matki jeszcze bardziej związała go z Maryją, do której Julianna przez swoje życie zanosiła swoje modlitwy. Mimo że Stefan Wyszyński mieszkał w Zuzeli jedynie niecałe dziewięć lat, to parafia zuzelska odegrała w jego życiu ważną, można powiedzieć formacyjną rolę. Dowodem na to są jego wspomnienia i odwołania do lat spędzonych w Zuzeli, między innymi podpis na wydanej przez siebie publikacji: „Dr Stefan Zuzelski”. Podpis ten pojawia się w 1931 r. w artykule pt. „Świat katolicki w 40-stą rocznicę encykliki Rerum novarum”. Podpis można tłumaczyć sytuacją społeczno-polityczną, ale zapytany odpowiada: „Chciałem dać przez to dowód mojej głębokiej czci do miejsca swego urodzenia. Jestem z Zuzelą związany" (Śliwowa 7).

Co ciekawe, od czasu objęcia urzędów kościelnych biskupa Stefan Wyszyński odbył tylko jedną oficjalną wizytę w parafii w Zuzeli (choć bywał tam wielokrotnie nioficjalnie). Wygłosił wtedy znamienne kazanie cytowane we fragmencie na początku artykułu. Było to 13 czerwca 1971 r., o czym tak wspomina ks. proboszcz Krysztopa:

${ }^{8}$ Więcej o pseudonimach Stefana Wyszyńskiego zob. Laskowska 170. Ten temat opisuje także E. Czaczkowska (52-60). Por. też Wyszyński, Kazanie 11. 
Była wizytacja kanoniczna ks. biskupa Mikołaja w czwartek, piątek i sobotę. Dzień trzynastego był już przeznaczony na wizytę zacnego gościa, ks. Kardynała. Podczas prawie godzinnego kazania do ziomków Ks. Prymas relacjonuje, jak to było z przyjęciem biskupstwa. (Krysztopa, wywiad 2020)

Kardynał prosi ówczesnego Prymasa o dzień do namysłu. Przyjmuje tę nominację dopiero 26. Ten skrót myślowy, który zastosował w kazaniu zuzelskim, odsłania głębie duszy księdza Prymasa, to, co otrzymał od swoich kochanych rodziców i religijności, szczególnie maryjnej przed obrazem Matki Bożej Częstochowskiej w naszym kościele. Gdyby nie było tej pobożności kochanych rodziców czasów zuzelskich, prawdopodobnie ks. Stefan Wyszyński nie przyjąłby nominacji. Można postawić sobie pytanie retoryczne: Co byłoby, gdyby ks. Wyszyński nie przyjął tej nominacji. Co by było $\mathrm{z}$ Kościołem $\mathrm{w}$ Polsce $\mathrm{w}$ dalszych latach jego istnienia? Niech wielcy tego świata sobie odpowiedzą. Co byłoby, gdyby nie było małej miejscowości, nie byłoby tu Wyszyńskich przez 10 lat. Zapominamy o małych miejscowościach, w których ludzie pięknie żyją. (Krysztopa, wywiad 2021)

We wspomnianym kazaniu z 1971 r., wygłoszonym w kościele w Zuzeli, kardynał Wyszyński wielokrotnie wspomina swoje lata dziecięce tu spędzone. Jest ono ważnym i chyba najbogatszym publikowanym świadectwem Jego pamięci o tamtych czasach. Co istotne, Prymas Tysiąclecia nawet w tej oficjalnej sytuacji przywołał nie tylko przestrzeń sacrum, ale i okoliczności powszednie $\mathrm{z}$ domu rodzinnego:

Pamiętam pierwsze po obudzeniu się wejrzenie przez okno na niedaleki Bug 9 , którym płynęły berliny ze zbożem, świecąc z daleka białym płótnem żagli. Było to dla nas niezwykle ulubione zajęcie; prosto z łóżka biegliśmy do okna, aby je zobaczyć. (Wyszyński, Kazanie 10).

Aby zachować pamięć o sławnym ziomku, w 1982 r. przy parafii Przemienienia Pańskiego utworzony został Ośrodek Pamięci Kardynała Stefana Wyszyńskiego. To właśnie z jego inicjatywy została odrestaurowana chrzcielnica, przy której został ochrzczony Stefan Wyszyński. Zbudowano pomnik Prymasa (fot. 4), który stanął przed kościołem, a został pobłogosławiony przez Ojca Świętego Jana Pawła II. W 1987 r. pomnik uroczyście odsłonięto. Ośrodek Pamięci zajął się także rekonstrukcją budynku dawnej szkoły w celu jego adaptacji na salę szkolną z okresu młodości Stefana Wyszyńskiego oraz rekonstrukcji mieszkania Wyszyńskich. Muzeum uroczyście przekazano do dyspozycji pielgrzymów 14 października $1990 \mathrm{r}$.

\footnotetext{
${ }^{9}$ Warto zaznaczyć, że Bug zmienił koryto (płynął ongiś bliżej wioski) - dzisiaj z miejsca, w którym stał dom Wyszyńskich, nie widać już tej rzeki.
} 
Staraniem komitetu zbudowano w latach 1992-1994 dzwonnicę (fot. 5), mieszczącą trzy dzwony, z nadanymi kolejno imionami: Jan Paweł II (dzwon $3500 \mathrm{~kg})$, Stefan Wyszyński $(1800 \mathrm{~kg})$ oraz Jerzy Popiełuszko $(820 \mathrm{~kg})$. Poświęcił je Prymas Polski kard. Józef Glemp wraz z Episkopatem. W jubileusz 70-lecia kapłaństwa kardynała powstała w 1994 r. grota Matki Bożej z Lourdes, a w 100 rocznicę Jego urodzin w 2001 r. wmurowano kamienny obelisk z pamiątkową płytą (Krysztopa, wywiad 2020). Dziś, dla uczczenia postaci Kardynała, w centralnym punkcie parafialnego refektarza znajduje się strefa pamięci, gdzie zostało zdeponowanych wiele publikacji książkowych o Stefanie Wyszyńskim, a na ścianie jest zawieszony dużych rozmiarów portret Kardynała.

Podczas uroczystych obchodów 90. rocznicy święceń kapłańskich Prymasa Wyszyńskiego, odbywających się 2 sierpnia 2014 r., którym przewodniczyli prefekt Kongregacji Nauki Wiary kard. Gerhard Muller oraz metropolita warszawski kard. Kazimierz Nycz, zostało poświęconych „dwanaście witraży symbolicznie upamiętniających «Drogę życia Prymasa Tysiąclecia z Zuzeli do Warszawy ku świętości»" (Krysztopa, wywiad 2020) (fot. 6).

Pomimo że ziemska droga Stefana Wyszyńskiego zakończyła się 40 lat temu, jego duchowa obecność wciąż nam towarzyszy. Bardzo zauważalne jest to właśnie w Zuzeli, gdzie - by niejako zacytować Jana Pawła II - „wszystko się zaczęło". Pamięć o Prymasie Tysiąclecia trwająca w miejscu jego urodzenia została już w artykule częściowo zrekonstruowana. Aby odtworzyć współczesne losy rodziny Wyszyńskich, w kontekście ich związku z Zuzelą, w 2021 r. wywiad z Andrzejem Karpiem ${ }^{10}$, bliskim krewnym Prymasa Polski (jego dziadek był bratem matki Stefana Wyszyńskiego) oraz dodatkowy wywiad z obecnym proboszczem parafii w Zuzeli, ks. Jerzym Krysztopą.

Warte podkreślenia jest to, że odbywają się wspólne zjazdy rodziny kardynała Wyszyńskiego zarówno ze strony Jego matki, jak i ojca. Rodzina Karpiów spotykała się już wcześniej na zjazdach integracyjnych co pięć lat. Andrzej Karp tak o tym pisze:

Członkowie rodziny Karpiów przyjeżdżają z różnych stron Polski (Jelenia Góra, Duszniki Zdrój, Bydgoszcz i jej okolice, Wyszków i Warszawa). Jeżeli chodzi o rodzinę Wyszyńskich, to nie mieliśmy w tamtym czasie o nich wiedzy. Znaliśmy tylko rodzinę Agnieszki Kuczyńskiej, której babcia Franciszka była siostrą ojca Prymasa, Stanisława. (Karp, mps)

${ }^{10}$ Autorzy artykułu dziękują panu Andrzejowi Karpiowi także za udostępnienie dla potrzeb niniejszego tekstu jego niepublikowanych wspomnień (por. Karp, mps). 
Podczas spotkania Andrzeja Karpia i jego brata Marka z ks. Jerzym Krysztopą, proboszczem parafii w Zuzeli, w 2011 r. powstała idea wspólnych zjazdów całej rodziny Prymasa:

Pierwszy zjazd rodziny kardynała Wyszyńskiego odbył się w sierpniu 2012 r. w parafii pod wezwaniem Przemienienia Pańskiego w Zuzeli. Uczestniczyło w nim ok. 140 członków rodziny i zaproszonych gości. Po uroczystej mszy świętej, której przewodził biskup diecezji łomżyńskiej ks. Janusz Stepnowski, nastąpiło spotkanie integracyjne rodziny. Tam też poprosiliśmy księdza biskupa Janusza Stepnowskiego o patronat nad naszymi zjazdami. Prośba została spełniona. Do chwili obecnej odbyło się osiem zjazdów, najwięcej z nich w Zuzeli w miejscu urodzenia prymasa kardynała Stefana Wyszyńskiego. (Karp, mps)

W latach 2012-2016 odbyło się w Zuzeli pięć zjazdów rodzinnych Wyszyńskich i Karpiów, podczas których świętowano rocznice urodzin fizycznych i duchowych Stefana Wyszyńskiego. Podczas codziennej Mszy św. przez wiele lat odmawiana była modlitwa o beatyfikację Kardynała. Obecnie, w oczekiwania na uroczystą promulgację dekretu beatyfikacyjnego, odmawiana jest modlitwa o duchowe owoce beatyfikacji (Krysztopa, wywiad 2020). Zjazdy umacniały więzi rodzinne, były też zaczynem ważnych projektów:

Dotychczasowe zjazdy rodziny kard. Wyszyńskiego [...] dały również asumpt do opracowania genealogii rodziny Prymasa, tak od strony matki jak i ojca. Protoplastą rodu Karpiów, do którego dotarliśmy, był Stefan urodzony w 1767 r., a rodu Wyszyńskich Kazimierz Wyszyński urodzony w 1773 r. Jak z tego wynika, genealogia obu rodzin sięga końca XVIII wieku i składa się z 240 rodzin, czyli ok. 683 osób. (Karp, mps)

Współczesną pamięć o Stefanie Wyszyńskim podtrzymuje wspomniane już Muzeum Lat Dziecięcych Kardynała Stefana Wyszyńskiego w Zuzeli (fot. 7). Jego niestrudzonym kustoszem jest ks. Jerzy Krysztopa: „Wie Pan, jacy ludzie nie pozwolili zginąć dorobkowi myśli i pamiątek Kardynała Wyszyńskiego? To jest ksiądz Jerzy Krysztopa i panie z Instytutu Prymasa Wyszyńskiego. Dzięki tym ludziom jest to muzeum” (Karp, wywiad 2021).

W ramach Muzeum odtworzono przestrzeń w której wychowywał się i formował duchowo Stefan Wyszyński:

Muzeum jest zrekonstruowane $\mathrm{w}$ dawnym budynku szkoły powszechnej z XIX wieku, do której uczęszczał w latach 1908-1910 przyszły Prymas. W lewej części utworzono rekonstrukcję mieszkania Państwa Wyszyńskich w dawnym miesz- 
kaniu nauczycielskim, ponieważ organistówka, która znajdowała się obok szkoły, została całkowicie zniszczona podczas II wojny światowej. W rekonstrukcji jest ołtarzyk, przy którym modlili się Wyszyńscy. Odmawiali wspólny pacierz, ale mało się podkreśla, że Wyszyńscy przez cały rok odmawiali razem codziennie cząstkę Różańca. Zawsze prowadzącym modlitwy był Ojciec. Był odpowiedzialny nie tylko za utrzymanie rodziny, ale także za formację religijną i patriotyczną. Następnie za nim klęczały dzieci i na końcu matka, która pilnowała, aby dzieci dobrze zachowywały się podczas modlitwy. (Krysztopa, wywiad 2021)

Dzięki zgromadzonym eksponatom możemy się niejako przenieść w tamten czas, zrozumieć, jak wówczas funkcjonowała lokalna społeczność i rodzina wiejskiego organisty:

Jest szafka wiejskiego organisty, który ma w swoich zbiorach dzieła Reymonta, Kraszewskiego, Mickiewicza, Słowackiego, Norwida, Krasińskiego. Także Pismo Święte, książki religijne, historyczne, geograficzne. Widzimy w domu porcelanę, co znaczy, że status organisty był nieco wyższy od przeciętnego mieszkańca Zuzeli czy parafii. W Sali szkolnej widzimy oryginalną mapę ukazującą ogrom Rosji carskiej z początku XX wieku. (...) Jest także zdjęcie Stefana z rodzicami i rodzeństwem. Nie ma oryginalnego zdjęcia Stefana z mamą z czasów zuzelskich. Jest zdjęcie, gdzie Stefan jest z książką Historia Polski w 24 obrazkach, książką wówczas zakazaną. (Krysztopa, wywiad 2021)

Ksiądz proboszcz Jerzy Krysztopa angażuje się także w wiele innych lokalnych działań upamiętniających osobę Prymasa Tysiąclecia. Tak mówił w wywiadzie odnośnie do najważniejszych zrealizowanych przedsięwzięć i planów na przyszłość:

W Zuzeli funkcjonował Ośrodek Pamięci, który spełnił swoją rolę poprzez budowę pomnika, Muzeum Lat Dziecięcych Kardynała Stefana Wyszyńskiego w Zuzeli i wybudowaniu $\mathrm{w}$ dużej mierze dzwonnicy $\mathrm{z}$ trzema dzwonami poświęconymi trzem wielkim Polakom. Myślę, że czas na to, aby była kontynuacja tej pracy pedagogicznej, którą podjęliśmy tu na początku z siostrami Służkami Maryi Niepokalanej (...). Bardziej bym stawiał na średnie pokolenie, które trochę pamięta Księdza Kardynała. To pokolenie trzeba tak kształtować, aby miało odpowiednią wiedzę, determinację, aby przekazać to młodemu pokoleniu. Nie sposób ściągnąć tę młodzież do muzeum, które nie jest urządzone w sposób nowoczesny, audiowizualny. Potrzebny jest drugi budynek, który będzie spełniał te potrzeby młodych ludzi, adresowany do uczniów szkół średnich, szkół akademickich. Jest potrzeba wsparcia, aby mała Zuzela, parafia niespełna 1000 osób zastępowała zadanie, które jest dla całej Ojczyzny. (...) Nie szukajmy jakichś wielkich ideałów na Zachodzie, nie wiadomo gdzie, tylko poszukajmy w naszych małych ojczyznach (...). Nie dla siebie chcemy tu coś robić, ale dla tysięcy 
pielgrzymów. Jeżeli będzie pomoc, będziemy to realizować. (Krysztopa, wywiad 2021).

Kardynał Zenon Grocholewski nazwał Stefana Wyszyńskiego Mojżeszem Polski, który przeprowadził Naród Polski przez trudne czasy (Krysztopa, wywiad 2021). Ta piękna biblijna metafora odzwierciedla wkład Prymasa Tysiąclecia w najnowsze dzieje Polski. Zbliżająca się beatyfikacja będzie zapewne okazją do podsumowania Jego ogromnego dorobku. Obyśmy w przyszłości jeszcze przez wiele lat zbierali owoce z tego dobrego drzewa.

\section{BIBLIOGRAFIA}

\section{MATERIAŁY ŹRÓDŁOWE}

Karp, wywiad 2021 - Wywiad z Andrzejem Karpiem, krewnym matki Stefana Wyszyńskiego, przeprowadzony przez Radosława Wileńskiego 19.04.2021 r.

Krysztopa, wywiad 2020 - Wywiad z ks. Jerzym Krysztopą, proboszczem parafii Zuzela, przeprowadzony przez Radosława Wileńskiego 05.02.2020 r.

Krysztopa, wywiad 2021 - Wywiad z ks. Jerzym Krysztopą, proboszczem parafii Zuzela, przeprowadzony przez Radosława Wileńskiego 19.04.2021 r.

\section{LITERATURA}

Bystroń, Jan. Etnografia Polski. Czytelnik, 1947.

Bystroń, Jan. Kultura ludowa. Trzaska, Evert i Michalski, 1947.

Czaczkowska, Ewa. Kardynat Wyszyński. Biografia. Znak, 2013.

Czarnowski, Robert. Parafia Zuzela. Dzieje i duszpasterstwo w latach 1796-1925. Wydawnictwo Salezjańskie, 2006.

Karp, Andrzej. „W przeddzień beatyfikacji” [wywiad z Andrzejem Karpiem]. Caritas, nr 1, 2020, ss. 74-76.

Karp, mps - „Na plebanii w Zuzeli”, niepublikowany maszynopis autorstwa Andrzeja Karpia.

Kindziuk, Milena. Kardynat Stefan Wyszyński Prymas Polski. Esprit, 2019.

Laskowska, Małgorzata. „Praca dziennikarska i redaktorska ks. Stefana Wyszyńskiego w latach 1924-1946". Studia Prymasowskie UKSW (3), 2009, s. 52-60.

„Radujcie się, Pan jest blisko”. Mały Gość Niedzielny, nr 12, grudzień 2019.

Micewski, Andrzej. Kardynat Wyszyński Prymas i Mąż stanu. Éditions du dialogue, 1982.

Molka, Jacek. Wszystko o Prymasie Tysiaclecia. Wydawnictwo Świętego Filipa Apostoła, 2020.

Orszulik, Alojzy. Czas przełomu. Apostolicum, 2006.

Raina, Peter. Stefan kardynat Wyszyński. Prymas Tysiaclecia. LENA, 2020.

Ryszka, Czesław. Prymas Wyszyński ojciec ojczyzny. Biały Kruk, 2020.

Stefaniak, Piotr. Kardynat Stefan Wyszyński - Człowiek, który poprowadził Kościót i Naród ku wolności. Znak, 2019. 
Śliwowa, Zofia. Z Zuzeli na stolicę prymasów. Promyczek, Wydawnictwo im. Stefana Kardynała Wyszyńskiego „Soli Deo”, 2001.

Wileński, Radosław. Ludowe śpiewy religijne w obrzędzie pogrzebowym ze wsi Gasiorowo (parafia Zuzela $w$ diecezji łomżyńskiej). Analiza materiałów terenowych z lat 2019-2020. Praca magisterska. Promotor: dr hab. Tomasz Rokosz. KUL, 2020.

Wyszyński, Stefan. Kazanie Kardynała Stefana Wyszyńskiego Prymasa Polski. Zuzela 13 czerwca 1971. Parafia Przemienienia Pańskiego w Zuzeli, 2011 [tekst kazania transkrybowany z nagrania przez ks. Jerzego Krysztopę oraz Iwonę Czarcińską]

Wyszyński, Stefan. Wypetniamy Jasnogórskie Śluby Narodu. Jasna Góra, 2016.

Wyszyński, Stefan. Zapiski więzienne. Apostolicum, 2001.

\section{KUŹNIA CHARAKTERU, KORZENIE ŚWIĘTOŚCI - WIEŚ ZUZELA, MIEJSCE URODZENIA I PIERWSZYCH LAT ŻYCIA KARDYNAŁA STEFANA WYSZYŃSKIEGO}

Streszczenie

Autorzy skupiają się na analizie czasów dzieciństwa Stefana Wyszyńskiego - lata 19011910, spędzonych we wsi Zuzela. Miejscowość jego urodzenia i pierwszych lat życia rekonstruują jako wyjątkowe miejsce w życiu późniejszego Prymasa Polski, w którym zazna dobrodziejstwa pełnej rodziny - matczynej i ojcowskiej miłości. Zaważyły one na jego późniejszych wyborach życiowych, tak istotnych dla losów Kościoła w Polsce. Z perspektywy czasu Zuzela jawi się jako swoisty raj utracony, zwłaszcza w kontekście późniejszej przeprowadzki do Andrzejewa, gdzie wkrótce zmarła matka Stefana Wyszyńskiego - miał on wtedy zaledwie dziewięć lat. W artykule opisano także współczesne inicjatywy podjęte dla upamiętnienia osoby Prymasa Tysiąclecia. W szkicu wykorzystano zarówno materiały opublikowane, jak i źródła wywołane w czasie badań terenowych - na potrzeby artykułu zostały przeprowadzone wywiady $\mathrm{z}$ proboszczem parafii w Zuzeli, ks. Jerzym Krysztopą, oraz Andrzejem Karpiem, krewnym matki Stefana Wyszyńskiego.

Słowa kluczowe: Stefan Wyszyński; Julianna Wyszyńska (z domu Karp); Stanisław Wyszyński; Zuzela; Jerzy Krysztopa; Andrzej Karp.

\section{THE FORGE OF CHARACTER AND ROOTS OF HOLINESS: \\ THE VILLAGE OF ZUZELA, THE PLACE OF BIRTH AND FIRST YEARS OF LIFE OF CARDINAL STEFAN WYSZYŃSKI}

\section{Su m m ary}

The authors focus on the analysis of Stefan Wyszyński's childhood - the years 1901-1910, spent in the village of Zuzela. They reconstruct the place of his birth and the first years of his life as a unique place in the life of the future Primate of Poland, where he experienced the benefits of having a full family - maternal and paternal love. They influenced his later life choices, so important for the fate of the Church in Poland. In retrospect, Zuzela appears as a kind of lost paradise, especially in the context of his later move to Andrzejewo, where his mother died soon - he was only nine at this time. The article also describes contemporary initiatives undertaken to commemorate the Primate of the Millennium. The sketch uses both 
published materials and sources developed during the field research. For the purpose of the article, interview were made with Fr. Jerzy Krysztopa, the pastor of Zuzela, and Andrzej Karp, a relative of Wyszyński's mother.

Translated by Stanisław Sarek Proofread by Tomasz Patkowski

Keywords: Stefan Wyszyński; Julianna Wyszyńska (née Karp); Stanisław Wyszyński; Zuzela; Jerzy Krysztopa; Andrzej Karp. 


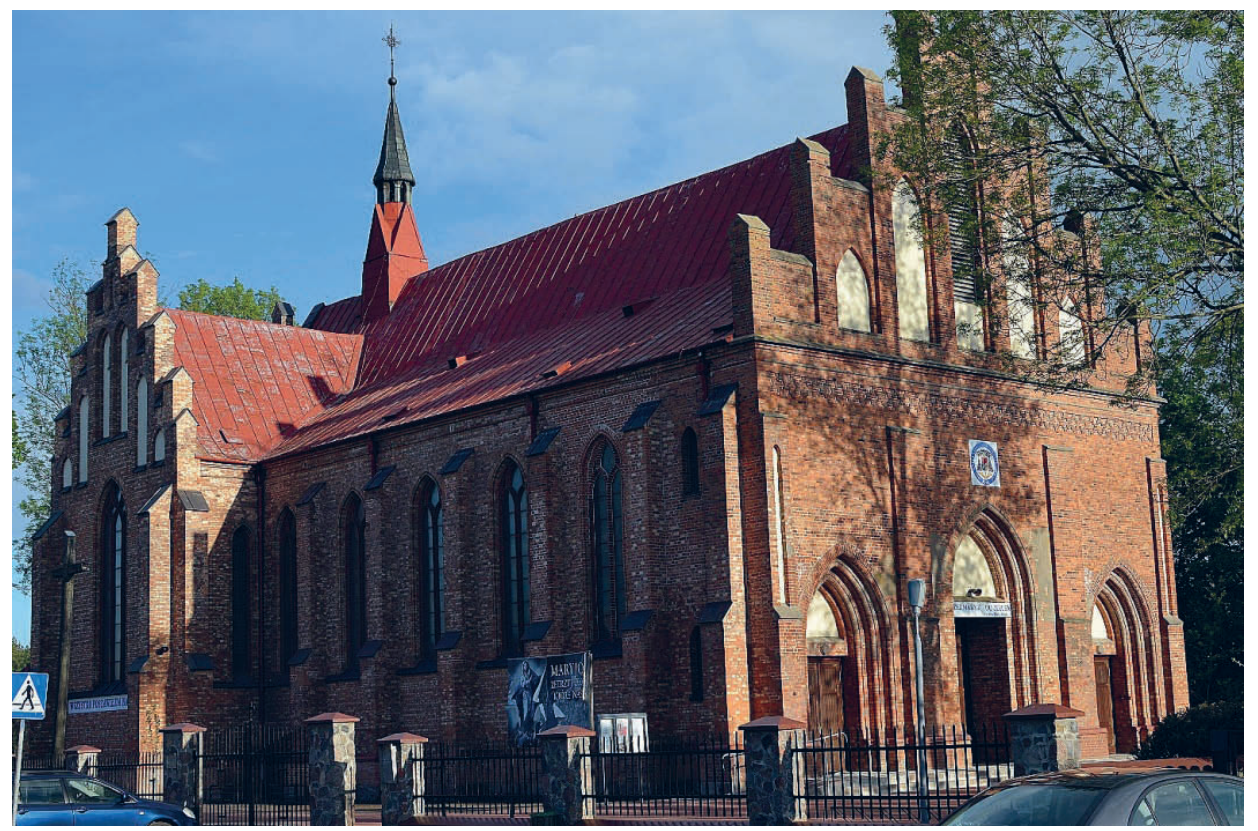

Fot. 1. Kościół w Zuzeli (fot. Radosław Wileński)

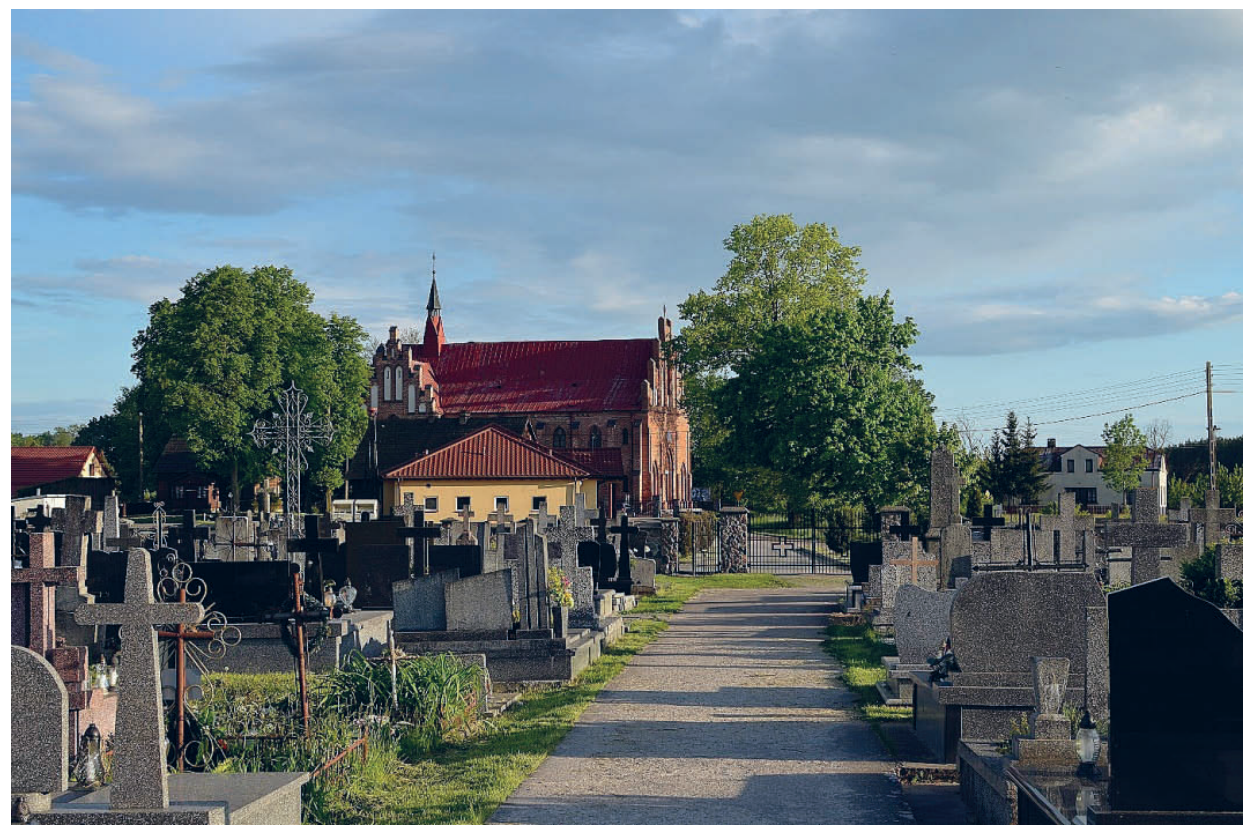

Fot. 2. Cmentarz parafialny w Zuzeli (fot. Radosław Wileński) 


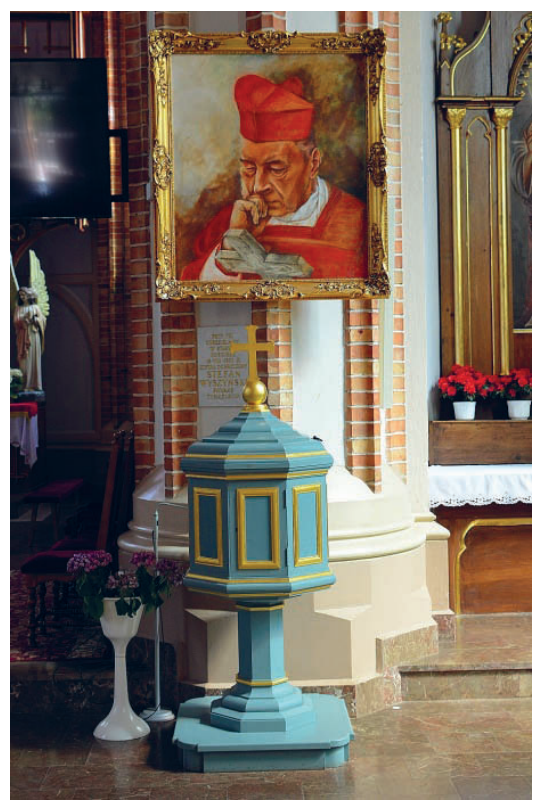

Fot. 3. Chrzcielnica, przy której był ochrzczony Stefan Wyszyński

(fot. Radosław Wileński)

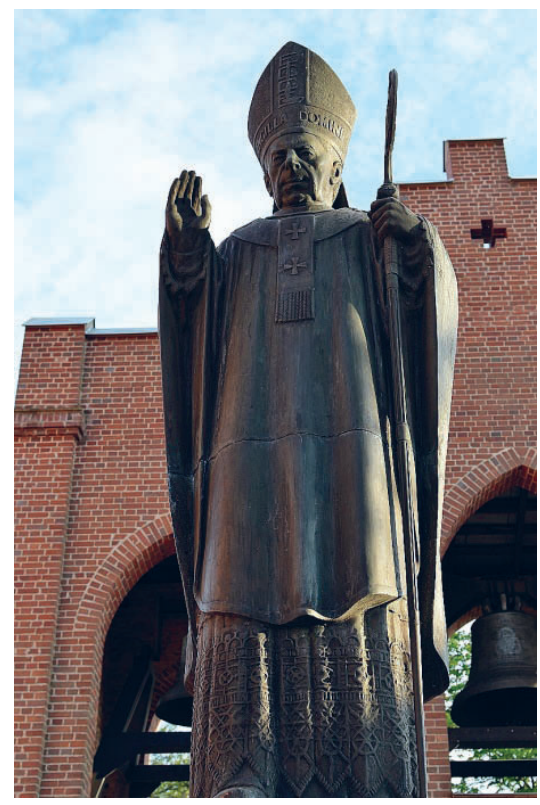

Fot. 4. Pomnik Prymasa Wyszyńskiego w Zuzeli poświęcony przez Ojca Świętego Jana Pawła II podczas III Pielgrzymki do Ojczyzny

(fot. Radosław Wileński)

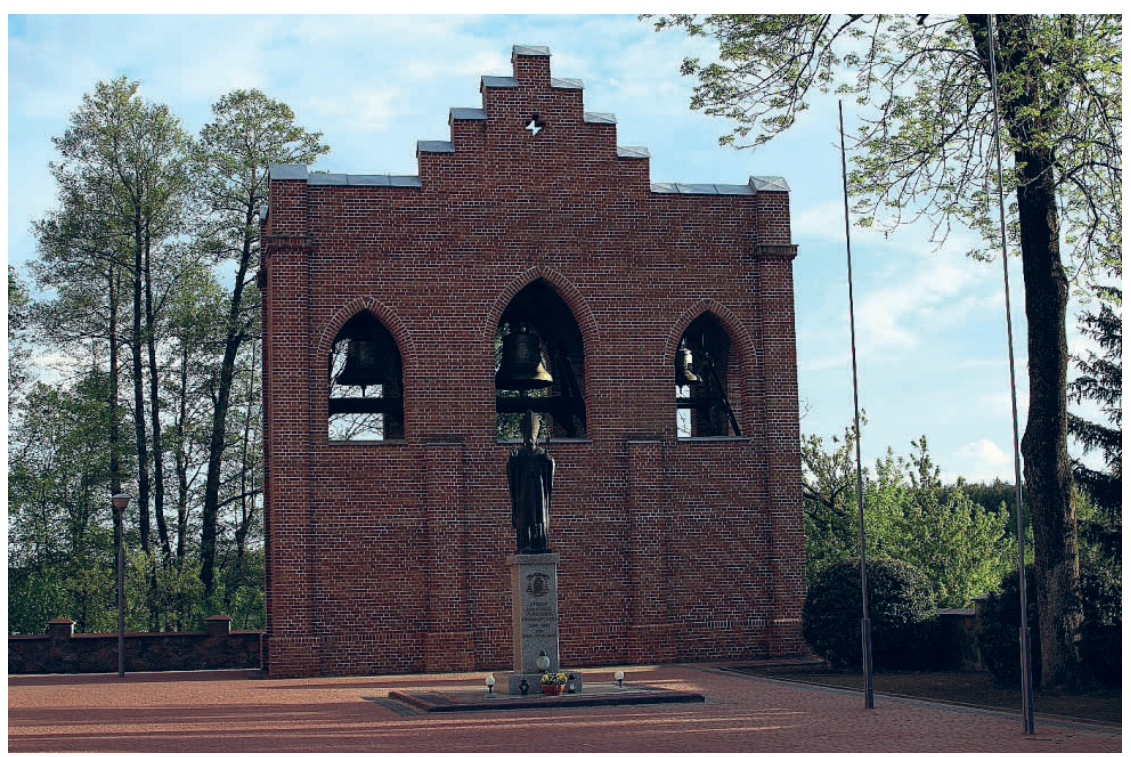

Fot. 5. Dzwonnica w Zuzeli (fot. Radosław Wileński) 


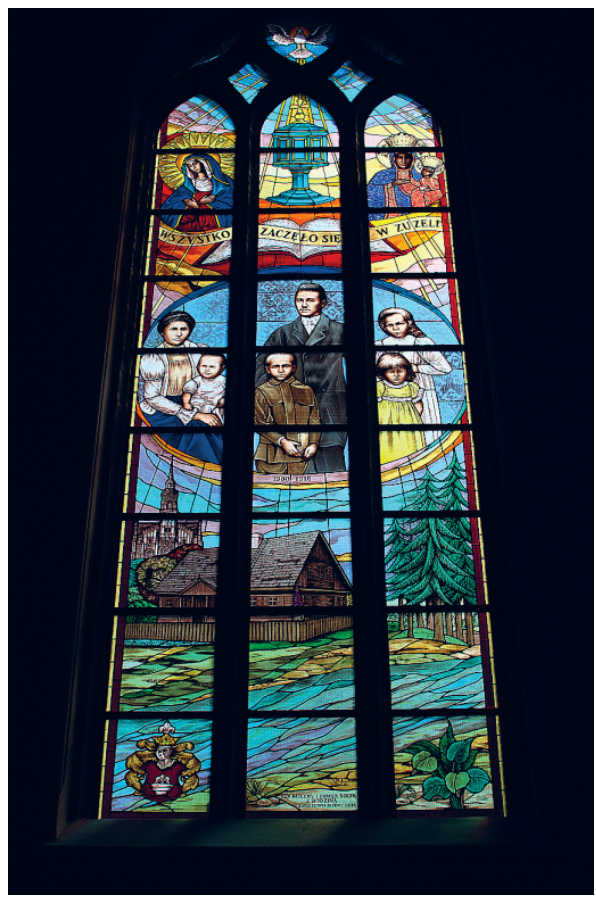

Fot. 6. Witraż w kościele w Zuzeli przedstawiający rodzinę Wyszyńskich (fot. Radosław Wileński)

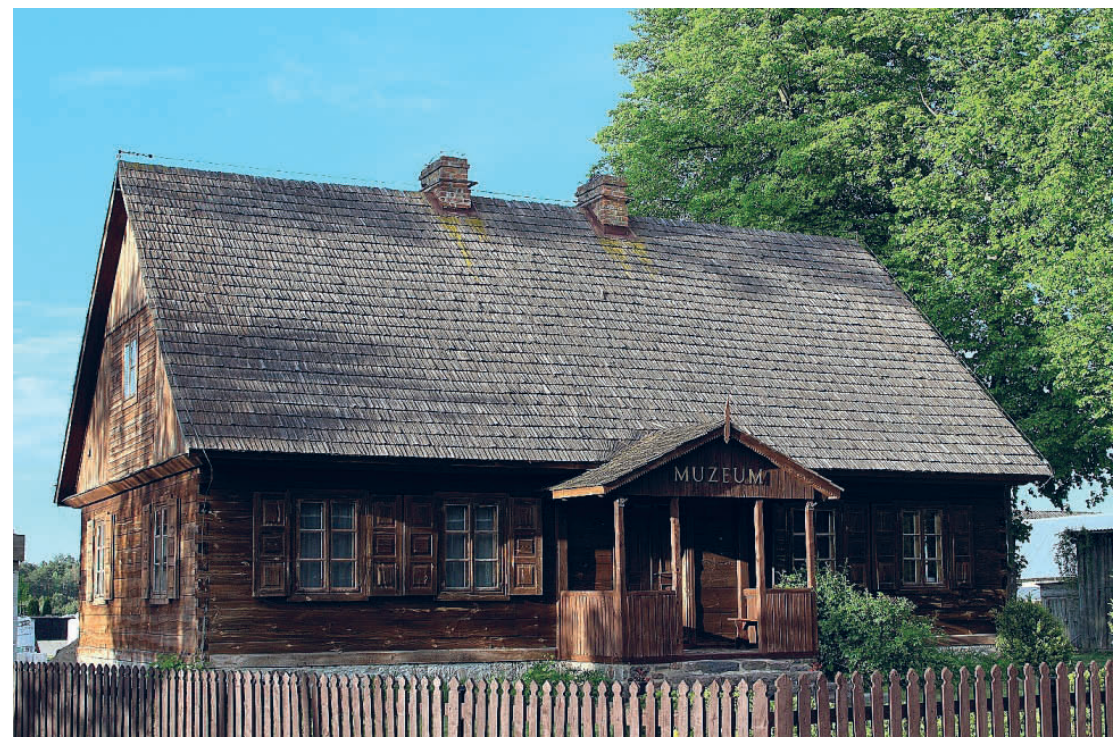

Fot. 7. Muzeum Lat Dziecięcych Kardynała Stefana Wyszyńskiego w Zuzeli (fot. Radosław Wileński) 